Toscano, R., Price, G., \& Scheepers, C. B. (2018). The impact of CEO arrogance on top management team attitudes. European Business Review, EBR-12-2016-0156 (accepted and in press)

\title{
The impact of CEO arrogance on top management team attitudes
}

\author{
Roberta Toscano, Gavin Price and Caren Scheepers \\ Leadership Cluster, University of Pretoria Gordon Institute of Business Science, Johannesburg, South \\ Africa
}

\begin{abstract}
Purpose - The purpose of this paper is to test the effects of CEO arrogance on key attitudes of a company's top management team (TMT).

Design/Method/Approach - An experimental design involving a business simulation is employed to test the effects of a CEO's perceived arrogance and humility on the TMT in a boardroom setting.
\end{abstract}

Findings - The study finds that, as predicted, arrogant CEOs adversely impacts TMT engagement, cohesiveness, collaboration and consensual decision-making. Thus, the higher the level of CEO arrogance, the lower the levels of positive TMT attitudes. The study intriguingly also finds that CEOs who displayed humility also negatively influenced the attitudes of the TMT.

Research limitations/implications - The study took place in South Africa, which may limit the generalizability of the findings. The use of a laboratory experiment may affect the ecological validity of the findings.

Practical Implications - The results demonstrate that a "Goldilocks" area of neutrality between arrogance and humility should be sought after by CEOs and recruiters of CEOs. If this is impossible, humble CEOs are preferable to arrogant ones.

Originality/Value - This paper empirically demonstrates that arrogant leaders negatively impact their TMT followers in a boardroom environment across a number of attitudes that are key to the success of effectively managing a corporation. The study 
also demonstrates that moderation is desired by followers and that CEOs being perceived as overly humble is almost as bad as being perceived as arrogant.

Keywords: Arrogance, Humility, CEO leadership, Top management team dynamics, Experimental design, Business simulation.

Media reports on CEO arrogance are commonplace (Finkelstein, 2011) and include the quoting of the Netflix CEO, admitting, "I slid into arrogance", when he abruptly increased prices without consulting subscribers, almost causing his company's downfall (Moyer, 2011). Studies such as those undertaken by Dotlich and Cairo (2003); Leslie and Van Velsor (1996); Hogan, Hogan and Kaiser (2011); Finkelstein (2004); Ma and Karri (2005); and Resick, Whitman, Weingarden and Hiller (2009), show that arrogance is one of the key causes of derailment and failure of leaders. Surprisingly, despite the fact that arrogance is a trait often found in business, it has not been empirically examined. Humility, on the other hand, has been proposed as a necessary component of successful CEOs (Collins, 2005; Nielsen, Marrone and Slay, 2010; Morris, Brotheridge and Urbanski, 2005; Ou, 2011; Vera and Rodriguez-Lopez, 2004). Since arrogance may be considered the antithesis of humility, it has research value as a unique predictor (Lopez and Snyder, 2009; Owens, 2009).

The above findings indicate the need to gain a better understanding of how CEO arrogance can influence the attitudes of the top management team (TMT), or board of directors (BOD). Since the TMTs and BOD set policy direction, it can make or break organizational success, and the CEO remains the most powerful member of the board (Nithiyanandan, 2011; Pearce II and Zahra, 1991). Awareness of how different levels of CEO arrogance can affect the TMT's dynamics and decision-making processes would enable business leaders to arm themselves against the detrimental effects of 
arrogance. Our study contributes to the focus on top decision-makers in organizations and brings the team level of analysis into the scope of strategic management research (Hambrick and Mason, 1984; Yamak, Nielsen and Escribá-Esteve, 2014).

We investigated whether CEO arrogance affected the attitudes of the TMT toward engagement, cohesiveness, collaboration, as well as consensual decision-making. Nkomo and Kriek (2011) emphasise the requirement of South African leaders to be open and flexible under changing circumstances. In addition, there is a scarcity of scholarly research on executive leadership in countries in Africa, including South Africa. These conditions created a particularly interesting setting for the study as "South African leaders are under increasing pressure to guide the organisation in a manner that is in tune with the political mandate of social transformation" (Magner, 2008, p.128).

\section{Theoretical background}

\section{Arrogance and humility}

Arrogance is defined as a sense of superiority and exaggerated self-importance, acted out with an overbearing manner and presumptuous claims, from the Latin, arrogare, meaning "to claim credit that one is not entitled to" (Finamore, 1998; Hareli and Weiner, 2000, 2002; Sedikides and Gregg, 2001; Kowalski, Walker, Wilkinson, Queen and Sharpe, 2003). Johnson, et al. (2010, p. 405) define arrogance as "a set of behaviors that communicates a person's exaggerated sense of superiority which is often accompanied by disparaging or belittling others". Arrogant behavior exaggerates the perception of the self as invincible and omnipotent, when the behaviour reaches the extreme (Ma and Karri, 2005). In the definitions of humility, the dualism between arrogance and humility is illustrated. For example humility has been defined as the 
"lack of arrogance, capacity to listen carefully, and egolessness" (Ahn and Ettner, 2014). Jeung and Yoon (2016) emphasise that humble leaders are less self-focussed and more likely to demonstrate self-transcendent attitudes than other leaders. Focht and Ponton (2015) also describe humility as "not promoting themselves, they put others first" (Focht and Ponton, 2015, p. 49). Sousa and Van Dierendonck (2017) concur that what they called, the servant leader, gives priority to the interest of others. Characteristics of authentic leaders have been described as intrinsically humble (Walters and Diab, 2016).

Understandably, arrogance is often considered undesirable. Ineffective leaders cause great misery for their followers and subordinates (Einarsen, Aasland and Skogstad, 2007; Hogan, Hogan and Kaiser, 2011) and arrogant leaders tend to cultivate an atmosphere of intimidation, stifling others' ability to collaborate and communicate, resulting in toxic organizational environments (Salanove, Llorens, Cifre and Martínez, 2012; Silverman, Johnson, McConnell and Carr, 2012). Characteristically, an arrogant manager has a sense of superiority and presents himself as inaccessible and potentially unapproachable, and does not listen well to others (Trumpeter, Watson and O'Leary, 2006). In this regard, Cragun and Sweetman (2016) warn that an arrogant leader is not willing to learn from others.

Arrogance is also differentiated from hubris, or exaggerated self-confidence and pride (Hayward and Hambrick, 1997). The current study is not investigating the origin of the perceived arrogance of a leader, for instance that a leader might be appearing arrogant due to intrapersonal personality traits like intro- or extraversion, instead, the study focuses on observable behaviour traits, according to the Johnson et al. (2010) validated scale of perceived arrogant behaviours. 
Further, Johnson et al. (2010) verified the convergent and discriminant validity of the assertion that arrogance is different from narcissism in several significant ways. Thus, our study utilized the Johnson et al. (2010) Arrogance Scale in the Workplace to measure the independent variable of interest, Level of Perceived CEO Arrogance (LPCA).

Understanding the effect of humility on the TMT's attitudes was also felt to be as important as that of arrogance, particularly as they are considered to be on opposite ends of a continuum. A positive view of humility in leadership was evidenced by Nielsen et al. (2010) and Ou (2011), while a negative view was reported by Exline and Geyer (2004). CEO humility has also been linked to enhanced TMT integration (Ou, Waldman and Peterson, 2015).

Prior to discussing the TMT attitudes, a deeper discussion follows around current constructs and research in leadership literature.

Yukl (2001) contends that, despite the plethora of definitions of leadership, the process of influence is consistent across several. Arrogant leadership could be contrasted with other forms of leadership, for example, moral leaders were found to demonstrate a sense of duty, concern for others and judge their own behaviour (Den Hoogh and Den Hartog, 2008). Authentic leadership in turn, promotes a positive ethical climate and relational transparency. Metcalf and Benn (2013) highlight that ethical and authentic leadership share an emphasis on honesty and openness. Transformational leaders are not necessary described as ethical, but this style requires leaders to be trusted to be effective. Ethical leaders use punishment to hold people accountable, whereas this is not necessarily the same for authentic and transformational leadership. Transformational leadership does not need to be self-aware, such as with authentic leadership. Autocratic leadership in turn, is known for using coercion and lack democratic process in decision making, as 
described by Van Vugt et al. (2004). This style had been the least popular characteristic of followers when choosing a leader. The way that this article describes "Arrogant" leaders, relates to the authoritarian, less open and low levels of caring towards the needs for others, as Johnson et al. (2010) offered in the valid and reliable scale on Arrogance.

\section{TMT attitudes}

Upper echelons theory (UET) posits that CEO characteristics manifest in the firm's strategic actions and, in this way, its future performance (Wang, Holmes, Oh and Zhu, 2015). The relationship between the TMT and the CEO is an important and intriguing company dynamic that has gained research momentum since Fama and Jensen (1983) described it as the peak of an organization's decision-making system. It is therefore imperative to study the nuances of the CEO and TMT relationship. Following and building on the works of Avolio, Gardner, Walumbwa, Luthans and May (2004) and DeRue, Nahrgang, Wellman and Humphrey (2011), this study investigated specific attitudes of TMT members. For example, Roberts, McNulty and Stiles (2005) emphasise the importance of board leadership on engagement of board members, and positive consequences of engagement are well established, such as proactive behaviour (Bakker, Tims and Derks, 2012) and thus engagement was included in this study. Other attitudes of TMT members that are included in this study are for example, cohesiveness that has an impact on whether the TMT members want to be part of the team. Collaboration at top management level has been shown to be highly beneficial to companies and thus was included in the study. Martyn (2006) claims that a consensual decision-making approach is an important determinant of a TMT's success and was the final attitude investigated in this study.

Engagement (ENG). The boardroom set-up is not an equal playing field for the TMT dynamic as the CEO is considered first among equals. The relationship may be 
equated to the follower-leader situation emphasized by Avolio et al. (2004). Wefald and Downey (2009) postulated that engagement manifests itself in many ways, such as being enthusiastic about serving the board, being proud of being a member and being willing to invest time to participate in the board's activities and decision-making. They also observed engagement in TMT members who felt that time flew during board meetings and had the propensity to forget everything else when attending them. Given the negative impact that arrogance appears to have on engagement, we developed the following hypothesis:

Hypothesis 1: There is a negative relationship between the Level of Perceived CEO Arrogance (LPCA) and the Engagement (ENG) of the TMT.

Cohesiveness (COH). Crandall (2007) as well as Kayworth and Leidner (2001, 2002) have explored a leader's impact on group cohesion. Group cohesion is defined by Martyn (2006) as the attractiveness of a group for its members, which is reflected in their motivation to be a part of it, and the level of resistance they have towards leaving the group. Carmeli, Friedman and Tishler (2013) demonstrated that the connectivity of TMTs was positively associated with both their resilience and the comprehensiveness of their strategic decisions. Treadwell, Lavertue, Kumar and Veeraraghavan (2001) argued that a cohesive group allows its members to be comfortable in expressing disagreement, thereby making discussions and decision-making a group effort. We therefore propose the following:

Hypothesis 2: There is a negative relationship between LPCA and the Cohesiveness (COH) of the TMT. 
Collaboration (COL). Alderfer (1986) argued that ongoing collaboration in decision-making between the CEO and the TMT is one of the best manifestations of the relationship between the two. Gulati and Westphal (1999) found that CEO and board collaboration and control are positively related to firm performance. LipmanBlumen (2000) further showed that a collaborative boardroom can deter aggression and hostility within the TMT and create a reservoir of goodwill between it and the CEO. Wall et al. (2004); as well as Mayle and Henry (2006), also emphasise the role of senior managers in fostering collaboration. We therefore consider collaboration an important construct, and predict:

Hypothesis 3: There is a negative relationship between the Level of Perceived CEO Arrogance (LPCA) and the Collaboration (COL) of the TMT.

Consensual Decision-making (CDM). Huse (2007) encourages a robust level of discussion with contributions from all top team members. Flood et al. (2000) emphasise leadership's role in the discussions towards consensus. Knight et al. (1999) note that consensual decision-making is manifested when BOD members agree that a decision is acceptable to them. That is to say, a decision is not final unless everybody agrees to it. Reaching a consensual decision requires hard work as there are a multitude of inputs that must be incorporated into the decision-making process. Millikin and $\mathrm{Fu}$ (2005) found that leadership affects the likelihood of consensual decision-making. Unfortunately, arrogance has a destructive effect as it exacerbates team member incompatibility, inhibits and disrupts team functioning (Anderson, Srivastava, Beer, Spataro and Chatman, 2006; Paulhus, 1998; Steiner, 1986). We therefore predict:

Hypothesis 4: There is a negative relationship between the Level of Perceived CEO Arrogance (LPCA) and the Consensual Decision-making (CDM) of the TMT. 
Studies have still not clarified whether the CEO's level of arrogance, as perceived by the TMT, affects the attitudes of this team (Tosi, Misangyi, Fanelli, Waldman, \& Yammarino, 2004; Ranft, Zinko, Ferris, \& Ronald Buckley, 2006). Our study therefore investigated the influence of CEO arrogance on their overall attitude. TMT Attitude (TMTA) was conceptualized as a second order construct, based on the four first order constructs: engagement, cohesiveness, collaboration and consensus. Our prediction with regard to TMT Attitude was:

Hypothesis 5: The Level of Perceived CEO Arrogance (LPCA) is a predictor of TMT Attitude (TMTA) among the members of the TMT.

\section{Method}

To ensure high levels of control, we created laboratory settings which replicated the boardroom environment and dynamics (Blumberg, Cooper and Schindler, 2005). Several studies have demonstrated that hypotheses concerning attitudes and behaviors can be successfully tested using an experimental approach (Claxton, Sculpher and Drummond, 2002; Hiltz, Johnson and Turoff, 1986; Fast, Sivanathan, Mayer and Galinsky, 2012). We followed Dieguez-Barreiro, Gonzalez-Benito, Galende, and Kondo (2014), who argue that when studying the nature and essence of TMTs, a simulation may be the only option.

\section{Research participants}

The participants were drawn from two groups: senior business consultants, working for a global management consulting company who were based in Johannesburg, South Africa and part-time executive Masters in Business Administration (MBA) students studying at the Gordon Institute of Business Science, University Pretoria, South Africa. Both groups were considered to be suitable proxies for TMT members. 


\section{Research procedure}

Execugame, a business simulation involving tasks similar to those performed by TMTs, was employed to increase the ecological validity of the experiment (MacDonald, 2007). We chose Execugame as it replicates the challenges and dynamics faced by TMTs and simulates a business environment in which various companies compete with each other in the production and marketing of two products. Although participants were led to believe that performance mattered, the study was designed so that their performance would have no effect on the research variables. We thus ensured that the simulation that was used provided a complex environment, sufficient to be considered by the participants to be "a very-near-real experience" Dieguez-Barreiro et al. (2014, p.88)

A blind design was used; participants did not know which treatment level was administered. They were also given a false explanation of the research purpose to deter them from discovering the hypotheses and thereby distorting the experiment. The deception issues were comprehensively addressed during a final debriefing session. Participants were randomly assigned to one of the 18 TMTs to ensure random assignment to the treatments (Arrogant-CEO, Neutral-CEO and Humble-CEO). A completely randomized design was thus followed (Dean and Voss, 1998; Ryan, and Morgan, 2007).

We selected external role-players to act as CEOs of the various TMT teams and instructed them on the behaviors, attitudes, body language and manners to exhibit during the simulation, according to each specific treatment (arrogant, neutral or humble). We conducted a pilot study to verify the feasibility and robustness of the experimental design. Feedback was provided on how to improve the clarity of the questionnaire, conduct of the CEO role players, as well as the design of the experiment. 
A separate scale was used to measure each of the four first-order constructs and items were adapted from previous research. Six items from the 14-item engagement scale used by Wefald and Downey (2009) were adapted to specifically measure Engagement. Six items from the 33-item Group Cohesiveness Scale, the Marlowe-Crowne Social Desirability Scale (MCSDS), developed by Treadwell et al. (2001) was used to measure Cohesiveness, and Consensual decision-making was measured using a purposively developed four-item scale. We conducted a construct validity investigation to ensure the measures accurately reflected the intended concepts.

\section{Data collection Results}

Of the 126 participants that took part in the Execugame, 53 were management consultants and 73 were part-time Executive MBA delegates. Forty-five participants were randomly assigned to boards chaired by arrogant CEOs, 41 by neutral CEOs and 40 by humble CEOs.

\section{Reliability and validity of the data}

The Cronbach's alpha coefficients computed on the 126 complete responses indicated an excellent degree of reliability per each construct with all the values in excess of 0.9 , as illustrated in Table 1 below:

Table 1. Cronbach's alpha coefficient for the four constructs

\begin{tabular}{llcll}
\hline & ENGAGEMENT & COHESIVENESS & COLLABORATION & ConDecMake \\
\hline Cronbach & .946 & .91 & .93 & .93 \\
Alpha & & & & \\
\hline
\end{tabular}

The suitability of the data for performing a factor analysis was assessed and confirmed.

Discriminant validity was confirmed as the variables (ENG, $\mathrm{COH}, \mathrm{COL}$ and $\mathrm{CDM}$ ), loaded significantly only on one factor and no cross-loadings existed. The results of the 
exploratory factor analysis thus supported the use of each of the TMT attitudes as separate scales in the study.

\section{Results of relationship analyses of the dependent variables}

Preliminary analysis confirmed that there was no violation of the assumptions of normality, linearity and homoscedasticity of any of the independent variables. Results of the relationship between CEO arrogance and the four TMT member attitudes (as well as the overall score TMTA), was investigated through Pearson correlation coefficients as well as a one-way ANOVA with planned comparisons for each of the five attitudes across the three groups (Arrogant-CEO, Neutral-CEO and Humble-CEO). Welch's test was used to confirm whether there was a statistically significant difference across the three treatment groups. The effect sizes assessment results are also calculated. Table 2 below summarizes these results for each of the dependent variables: Insert table 2 here

Table 2. Summary of statistical analyses of dependent variables

\begin{tabular}{|c|c|c|c|c|c|}
\hline $\begin{array}{l}\text { Dependent } \\
\text { variables }\end{array}$ & ENG & $\mathrm{COH}$ & COL & $\mathrm{CDM}$ & TMTA \\
\hline Pearson & -.745 & -.743 & -.549 & -.806 & -.813 \\
\hline coefficients & $\mathrm{p}=.000$ & $\mathrm{p}=.000$ & $\mathrm{p}=.000$ & $\mathrm{p}=.000$ & $\mathrm{p}=.000$ \\
\hline \multirow[t]{3}{*}{ Differences } & $F(2,123)$ & $\mathrm{F}(2,123)$ & $F(2,123)$ & $\mathrm{F}(2,123)$ & $F(2,123)$ \\
\hline & $=111.2$ & $=121.7$ & $=42.8$ & $=169.7$ & $=203.2$ \\
\hline & $\mathrm{p}=.000$ & $\mathrm{p}=.000$ & $\mathrm{p}=.000$ & $\mathrm{p}=.000$ & $\mathrm{p}=.000$ \\
\hline Welch's test & $\mathrm{p}=.000$ & $\mathrm{p}=.000$ & $\mathrm{p}=.000$ & $\mathrm{p}=.000$ & $\mathrm{p}=.000$ \\
\hline Cohen's test: & .64 & .66 & .41 & .64 & .78 \\
\hline
\end{tabular}

The table above shows a strong negative correlation between the two variables, CEO arrogance and the Engagement of the TMT. High levels of arrogance on the part of the 
CEO are associated with a lower level of TMT engagement. Furthermore, there was a statistically significant difference in the ENG mean score for the three treatment conditions. The output of the Welch's test $(p=0.000)$ confirmed that there was a statistically significant difference across the three groups. The effect size, calculated using Cohen's (1988, as cited in Pallant 2010) eta squared, was 0.64, which was considered to be a large effect size. The ENG mean scores are also ordered from the lowest to the highest as hypothesized (Arrogant, $\mathrm{M}=16.4$; Neutral, $\mathrm{M}=25.1$; Humble, $M=25.4$ ) with contrast coefficients of $-1,0,1$ respectively.

CEO arrogance and Cohesiveness were also negatively correlated. $\mathrm{COH}$ mean score for the arrogant $\mathrm{CEO}$ group was lower than the $\mathrm{COH}$ mean score for the neutral CEO group, which was in turn lower than the $\mathrm{COH}$ mean scores for the humble $\mathrm{CEO}$ group. The ANOVA with planned comparisons was performed and the $\mathrm{COH}$ mean score for the arrogant group $(\mathrm{M}=14.8)$ was lower than the $\mathrm{COH}$ mean score for the humble group ( $\mathrm{M}=21.7)$. However, the mean $\mathrm{COH}$ score for the neutral group $(\mathrm{M}=22)$ was higher than the mean for the humble group. There was furthermore a statistically significant difference in the $\mathrm{COH}$ scores for the three different groups. The Pearson's correlation proved the existence of a negative relationship between CEO arrogance and COL as well. The COL mean scores for the three groups (Arrogant-CEO, Neutral-CEO and Humble-CEO) were ordered according to a monotonic sequence, with the Arrogant CEO group having the lowest COL mean, followed respectively by the Neutral CEO group and then the Humble CEO group. The COL mean scores for the three groups were Arrogant, $\mathrm{M}=17$; Neutral, $\mathrm{M}=21$; Humble $\mathrm{M}=21$.

A negative relationship between CEO arrogance and Consensual Decision-Making was also found. The CDM mean scores for the Arrogant CEO group were lower than the CDM mean scores for the Neutral CEO, which were in turn lower than the CDM mean 
scores for the Humble CEO groups. Interestingly, the Neutral group registered a CDM mean score higher than the Humble CEO group. The results indicate a large effect size. Prior to testing the correlation, the total TMT attitude (TTMTA) score was constructed as a weighted factor-based scale using all the variables (ENG, $\mathrm{COH}, \mathrm{COL}$, and CDM) and using the respective factor loadings resulting from the exploratory analysis (De Vaus, 2002). The factor-based approach used the 126 respondents' standardized scores on each variable, rather than the raw data. The raw data was multiplied by the factor loadings resulting from the exploratory factor analysis. Correlation analysis, using Pearson's correlation, revealed a strong negative correlation between LPCA and TTMTA. Planned contrasts were used to compare the TMTA scores across the three treatments. The coefficient used for the contrasts are $-1,0,1$ respectively for the three groups. The overall effect across the three conditions was significant.

To control for the influence of the demographic variables that may have had an influence on the outcome of the analysis, the demographic variables (gender, age, home language and industry) were entered first as a block in the regression analysis. For the test modelling, only one dependent variable was needed. Therefore, the dependent variable was constructed as the average of the four dimensions (ENG score, COH score, COL score, and CDM score) and named 'Total Attitudes Score'. The results showed that the demographic variables that were entered as the first block explained $14.7 \%$ of the variance in the dependent variable, which is the sum of the TMT's attitude scores. After the entry of the CEO arrogance (LCPA) independent variable, the total variance explained by the model as a whole was $67.5 \%$. The variable CEO arrogance thus explained an additional $53.8 \%$ of the variance in the total attitude ratings after controlling for the effects of the demographic variables. In the final model, only the Level of the perceived CEO Arrogance (LPCA) was found to be a significant predictor 
of the Total Top Management Team Attitude (TTMTA) score. The ANOVA Table 3 below shows that the model as a whole (including both blocks of variables) was significant. The demographic variables did not influence the outcome of the experiment. Table 4 contains details of the hierarchical multiple regression.

Table 3. ANOVA Summary

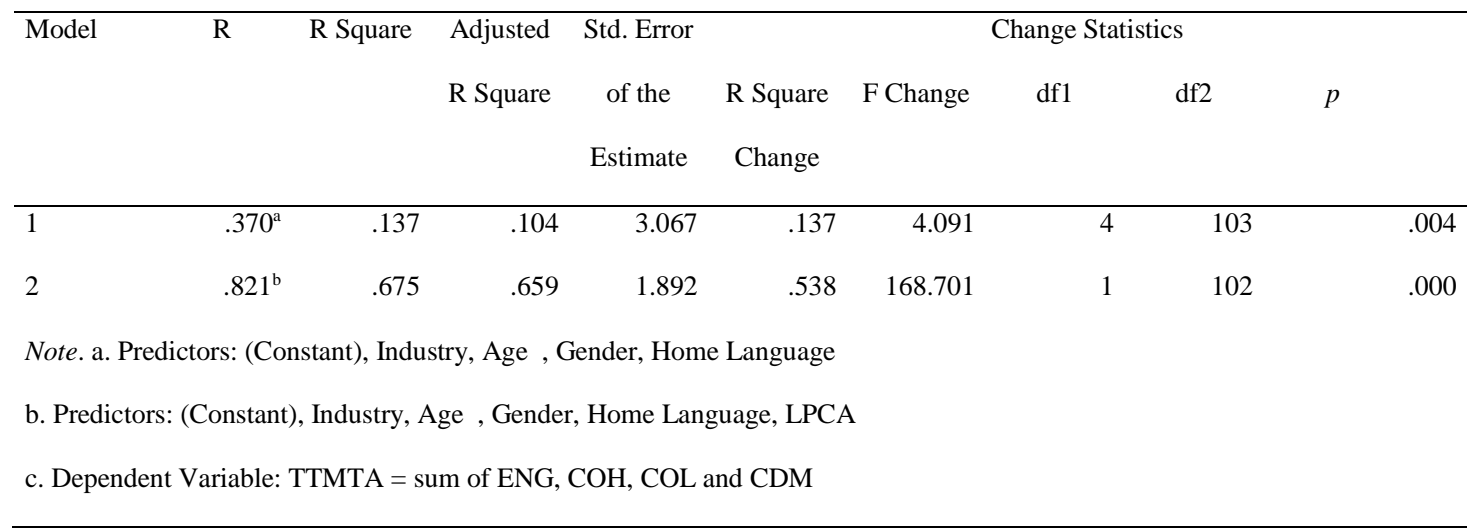

Table 4. Hierarchical Multiple Regression

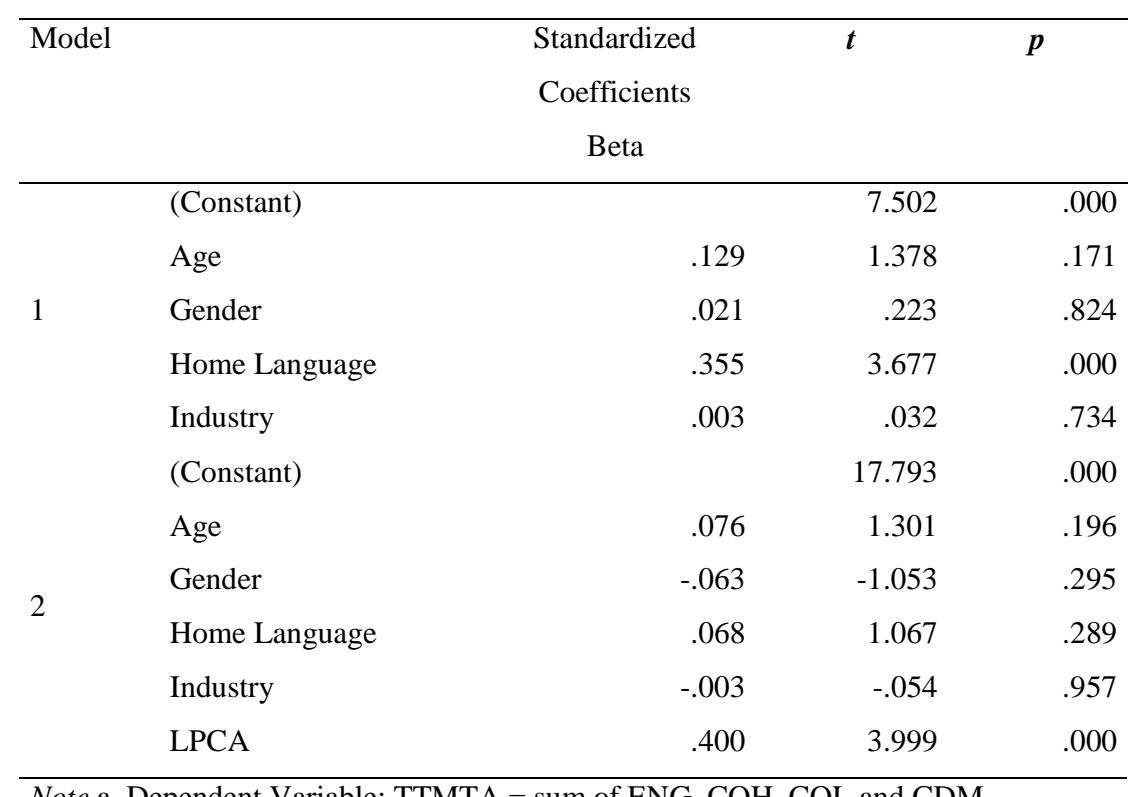

Note a. Dependent Variable: TTMTA = sum of ENG, COH, COL and CDM.

To measure the effectiveness of the manipulation of LCPA, participants were asked to rate the CEO using a five-point scale: highly arrogant, arrogant, neither arrogant nor humble, humble and highly humble. They also rated specific behaviors (eight items). 
The higher the score, the more arrogant the CEO was perceived to be. A chi-square goodness-of-fit test indicated that there was no significant difference in the proportion of participants who perceived their CEO as arrogant $(n=43)$ and the expected responses. The Kruskal-Wallis test was then used to compare the total arrogance score (sum of the eight items) for the five categories: highly arrogant, arrogant, neither arrogant nor humble, humble and highly humble. It revealed a statistically significant difference in the LPCA scores across the five perceptions. The group who claimed to be exposed to a highly arrogant $\mathrm{CEO}$ recorded a higher mean score for arrogance $(\mathrm{M}=$ 109) than the other four groups. In other words, the CEOs who were instructed to be highly arrogant were perceived as such. The same consideration applied to the other levels of arrogance. In conclusion, the manipulation of the independent variable was effective.

\section{Discussion}

\section{Statistical analyses}

All hypotheses were supported, suggesting that CEO arrogance had a negative relationship with the attitudes of the TMT. The higher the level of CEO arrogance, the lower the level of engagement, cohesiveness, collaboration and consensual decisionmaking. The implications of these findings are discussed below.

Engagement. Under the leadership of an arrogant CEO, the TMT may not be proud to be a member of the team, nor enthusiastic about serving the company. The results also suggested that the TMT might not be willing to invest time in top team activities and decision-making. The lower level of engagement under an arrogant CEO may also predict the TMT's predilection to think about other things when in boardroom meetings. The findings also support Huse (2007), who stated that top team dynamics and particularly boards, should allow for a robust level of discussion with contributions 
from all directors. In the same vein, Roberts et al. (2005: 13) claimed that board leadership is "vital to the board members" engagement, as it sets the culture of the board.

Cohesiveness. There was a significant and ordered difference in the level of cohesiveness among members of the TMT depending on whether they were working with an arrogant, neutral or humble CEO. The lack of equivalence in the level of cohesiveness implies that there were differences in the number of positive relationships and unity among members of the TMT, as set out in the study by Treadwell et al. (2001). There will also be differences in how comfortable the TMT feels in expressing its disagreement. Like Crandall (2007), Kayworth and Leidner (2001, 2002) believe that leaders are in a position to create an environment that fosters team unity and cohesion, which supports a negative correlation between CEO arrogance and cohesiveness of the TMT. What was interesting in this study was that the groups chaired by neutral CEOs were slightly more cohesive than those chaired by humble CEOs. This finding suggests that to create highly cohesive boards, CEOs should perhaps not strive for humble behavior. Instead, from the perspective of the participants of the study, it proved better to be perceived as neither arrogant nor humble.

Collaboration. The lowest collaboration was amongst TMTs headed by arrogant CEOs. This finding supports the studies of Mayle and Henry (2006), which showed a need for managerial support to embed collaboration among individuals within a firm. Wall et al. (2004) also provided support for hypothesis 3, arguing that senior management must foster collaboration among individuals as a top priority. The significant difference in the mean scores suggests that there might be differences in the trust and respect among members of TMTs. The results also indicated there may be differences in the difficulty or ease of communication among members of TMTs. 
Consensual decision-making. The study revealed that a humble CEO would enjoy a higher level of consensus among TMT members than an arrogant CEO. The inclination of the TMT to agree with decisions made in the boardroom may vary within the three arrogance level contexts. The extent to which each top team member's inputs are taken into account may also differ depending on the level of CEO arrogance, as will the level of hard work and time expended by the TMT to reach a decision. This supports Flood et al. (2000), who found direct and indirect relationships between leadership styles and consensus by focusing on 79 high technology firms. Millikin and Fu (2005) suggested that the management and leadership style espoused in an organization affects the likelihood of consensual decision-making. The TMTs led by neutral CEOs in this study were slightly more able to reach consensus than those chaired by humble CEOs. This finding suggests that, to create consensus in the TMT, the CEO should not strive for humble behaviors.

CEO arrogance as a predictor of TMT attitudes. The level of perceived CEO arrogance was a strong predictor of TMT attitudes. Arrogance explained almost $60 \%$ of the variance in the ratings. In other words, the study revealed that neither gender nor home language nor industries of expertise were predictors of the TMT's attitudes. Only the age of the TMT appeared to influence their attitudes, although only to a small extent. The findings provided strong evidence to support the argument that CEO arrogance played a high influencing role in determining the TMT's levels of engagement, cohesiveness, collaboration and consensual decision-making. Our study found gender, language (a proxy of ethnic group) and industry non-significant predictors of attitudes, opposing the findings of Riordan and Shore (1997), who argued that race greatly affected employee attitudes on work group. They did find, however, that gender had non-significant predictive power to gauge an employee's perception on tenure. Our 
current study therefore adds weight to Riordan and Shore's (1997) findings, validating the fact that gender was not a significant predictor of attitudes.

\section{Implications of the study}

There is increasing evidence in the leadership and psychology literature that personality is a predictor of leadership effectiveness (Borghans, Duckworth, Heckman and ter Weel, 2008; DeRue et al., 2011, Zaccaro, 2007). The findings of this study add weight to these theories by confirming that CEO arrogance is a strong predictor of the levels of engagement, cohesiveness, collaboration and consensus amongst the TMT. The study was able to distinguish between highly arrogant and arrogant CEOs, and compare them to both humble and highly humble CEOs. The support for all the hypotheses suggests that one way to bring about high levels of positive attitudes in the TMT is for the CEO to avoid displaying arrogance when heading the TMT. Within the particular context of a CEO's behavior in South Africa, Nkomo and Kriek (2011) emphasise the importance of a leader's mindset and their personal acceptance of changes that are occurring. By implication, an arrogant CEO would probably not be prepared to readily demonstrate acceptance to necessary changes. The damage caused by an arrogant CEO might even be worse within these trying circumstances of transformational change in South Africa.

The slight differences found in the levels of TMT attitudes under humble and neutral CEOs contradicted Collins (2005), whose study claimed that humility was a necessary trait for successful leadership. They found the level of collaboration within TMTs was higher when there was a humble CEO rather than an arrogant or neutral CEO. As far as collaboration was concerned, this study supports Collins (2005) in establishing humility as a necessary trait. Our study, however, found neutral CEOs brought out higher levels of cohesiveness and consensus than humble CEOs. Newman, Tyler and Dunbar (2001) 
argued that many individuals should participate in CEO performance appraisals. They also stated that the most influential input should come from members of the TMT. Senior teams should therefore consider feedback mechanisms, whereby the TMT and CEO provide behavioral feedback to one another, and discuss the impact of behavior on their attitudes.

The findings suggest that CEOs should curb arrogance towards their TMTs and leadership development interventions should purposefully coach CEOs on what constitutes arrogant behavior and how it impacts on TMT effectiveness. In this regard, Magner (2008, p. 129) laments that "the system of leadership in corporate South Africa needs to create trust amongst groups of peers". Seneque and Bond (2012) call for a reconceptualization of leadership in the context of South Africa in transition and for example discussed leadership as service, in line with Raelin's (2016) thesis that leadership is about facilitating the dedicated activities of those doing the work. The characteristics of the arrogant CEO are thus in direct contrast to what is required in the context of a society in transition, such as in South Africa.

\section{Limitations and suggestions for future research}

We opted to simulate an artificial boardroom environment, rather than collect data by observing real TMTs, which could have affected the generalizability of the findings. We mitigated this, however, by replicating board meeting dynamics and simulating a competitive business environment, thus improving ecological validity. The use of role players instead of CEOs may also have limited generalizability. This was partially mitigated by using senior people with managerial expertise as CEO-role-players.

To broaden understanding of the impact of CEO arrogance, future studies should investigate the impact of CEO arrogance on other variables. For example, CEO 
arrogance can affect other important organizational outcomes such as strategic dynamism, changes in resource allocation, research and development intensity, financial leverage and organizational performance at large (Chatterjee and Hambrick, 2007; Westphal, Seidel and Stewart, 2001). An interesting finding was the predictive power of age on TMT attitudes, suggesting a need to further explore this influence.

Zaccaro (2007) advises against focus on a single trait and suggests a combination of traits and attributes, integrated in conceptually meaningful ways. Further links between personality and leadership effectiveness should thus also be the focus of further investigations. A qualitative study to explore the current study's findings could be interesting to deeper understand and explanations of the parameters at play as well as the relationship between the constructs of arrogance and humility and the ultimate attitudes of TMT's. In today's world of virtual teams and e-leadership, the impact of a leader's arrogance on TMT attitudes could be even worse (Avolio, Kahai and Dodge, 2000).

\section{Conclusion}

This study provides evidence into the negative impact of arrogant CEOs on the attitudes of their top management teams. It supports the so-called Goldilocks principle: If CEOs are to be "just right", they should be neither arrogant, nor humble, but somewhere in between. And if this is not possible, organizations should err on the side of appointing humble, rather than an arrogant, CEOs, especially in the South African context.

\section{References}

Ahn, M. and W. Ettner, L. (2014), “Are leadership values different across generations? A comparative leadership analysis of CEOs v. MBAs", Journal of Management Development, Vol. 33 No.10, pp. 977-990.

Alderfer, C. P. (1986), "The invisible director on corporate boards", Harvard Business Review, Vol. 64 No.6, pp. 38-52. 
Anderson, C., Srivastava, S., Beer, J. S., Spataro, S. E., and Chatman, J. A. (2006), "Knowing your place: Self-perceptions of status in face-to-face groups", Journal of Personality and Social Psychology, Vol. 91 No.6, pp. 1094-1110.

Avolio, B. J., Kahai, S., and Dodge, G.E. (2000), "E-leadership: Implications for theory, research, and practice", Leadership Quarterly, Vol.11 No.4, pp. 615.

Avolio, B. J., Gardner, W. L., Walumbwa, F. O., Luthans, F., and May, D. R. (2004), "Unlocking the mask: A look at the process by which authentic leaders impact follower attitudes and behaviors", Leadership Quarterly, Vol.15 No.6, pp. 801823.

Bakker, A. B., Tims, M., and Derks, D. (2012), "Proactive personality and job performance. The role of jobcrafting and work engagement", Journal of Human Relations, Vol.65 No.10, pp. 1359-1378.

Blumberg, B., Cooper, D. R., and Schindler, P. S. (2005), Business research methods, Maidenhead: McGraw-Hill Education.

Borghans, L., Duckworth, A. L., Heckman, J. J., and ter Weel, B. (2008), "The economics and psychology of personality traits", Journal of Human Resources, Vol. 43 No.4, pp. 972-1059.

Carmeli, A., Friedman, Y., and Tishler, A. (2013), "Cultivating a resilient top management team: The importance of relational connections and strategic decision comprehensiveness", Safety Science, Vol.51 No.1, pp. 148-159.

Chatterjee, A., and Hambrick, D. C. (2007), "It's all about me: Narcissistic chief executive officers and their effects on company strategy and performance", Administrative Science Quarterly, Vol.52 No.3, pp. 351-386.

Claxton, K., Sculpher, M., and Drummond, M. (2002), "A rational framework for decision making by the National Institute for Clinical Excellence (NICE)", Lancet, Vol.360 No.9334, pp. 711.

Collins, J. C. (2005), "Level 5 leadership: The triumph of humility and fierce resolve", Harvard Business Review, Vol.83 No.7, pp. 136-146.

Cragun, S., and Sweetman, K. (2016), "Book Highlight—The Six Deadly Blindfolds: Why Individuals and Organizations Slip into Irrelevance and Ultimately Fail”, Global Business and Organizational Excellence, Nov/Dec, pp. 98-108.

Crandall, D. (Ed.). (2007), Leadership lessons from West Point (1st ed.), Jossey-Bass, San Francisco.

De Vaus, D. A. (2002), Surveys in social research (5th ed.), Allen \& Unwin, New South Wales.

Dean, A., and Voss, D. (1998), Design and analysis of experiments. Springer, Columbus.

Den Hoogh, A. H. B., and Den Hartog, D. N. (2008), "Ethical and despotic leadership, relationships with leader's social responsibility, top management team effectiveness and subordinates' optimism: A multi-method study", The Leadership Quarterly, Vol.19 No.3, pp. 297-311. 
DeRue, D. S., Nahrgang, J. D., Wellman, N., and Humphrey, S. E. (2011), “Trait and behavioral theories of leadership: An integration and meta-analytic test of their relative validity", Personnel Psychology, Vol.64 No.1, pp. 7-52.

Dieguez-Barreiro, J. H., Gonzalez-Benito, J., Galende, J., and Kondo, E. K. (2014), "The use of management games in the management research agenda", Developments in Business Simulation and Experiential Learning, Vol. 38, pp. 83-90.

Dotlich, D. L., and Cairo, P. C. (2003), Why CEOs fail: The 11 behaviors that can derail your climb to the top - and how to manage them (1st ed.), Jossey-Bass, San Francisco.

Einarsen, S., Aasland, M. S., and Skogstad, A. (2007), "Destructive leadership behaviour: A definition and conceptual model", Leadership Quarterly, Vol. 18 No.3, pp. 207-216.

Exline, J. J., and Geyer, A. L. (2004), "Perceptions of humility: A preliminary study", Self \& Identity, Vol.3 No.2, pp. 95-114.

Fama, E. F., and Jensen, M. C. (1983), "Separation of ownership and control", Journal of Law \& Economics, Vol.26 No.2, pp. 301-326.

Fast, N. J., Sivanathan, N., Mayer, N. D., and Galinsky, A. D. (2012), "Power and overconfident decision-making", Organizational Behavior \& Human Decision Processes, Vol.117 No.2, pp. 249-260.

Finamore, J. F. (1998), "Etymology and word histories", Classical Journal, Vol.93 No.3, pp. 285-289.

Finkelstein, S. (2011), “The worst C.E.O.'s of 2011”, The New York Times, viewed 27 December 2011, from http://dealbook.nytimes.com/2011/12/27/the-worst-c-e-o-sof-2011/.

Finkelstein, S. (2004), "The seven habits of spectacularly unsuccessful executives", Ivey Business Journal, Vol.68 No.3, pp. 1-6.

Flood, P. C., Hannan, E., Smith, K. G., Turner, T., West, M. A., and Dawson, J. (2000), "Chief executive leadership style, consensus decision making, and top management team effectiveness", European Journal of Work \& Organizational Psychology, Vol.9 No.3, pp. 401-420.

Focht, A., and Ponton, M. (2015), "Identifying primary characteristics of servant leadership: Delphi study”, International Journal of Leadership Studies, Vol.9 No. 1, pp.44-61.

Gulati, R., and Westphal, J. D. (1999), "Cooperative or controlling? The effects of CEO-board relations and the content of interlocks on the formation of joint ventures", Administrative Science Quarterly, Vol. 44 No.3, pp. 473-506.

Hambrick, D. C., and Mason, P. A. (1984), "Upper echelons: The organization as a reflection of its top managers", Academy of Management Review, Vol.9, pp.193206.

Hareli, S., and Weiner, B. (2000), "Accounts for success as determinants of perceived arrogance and modesty", Motivation and Emotion, Vol.24 No.3, pp. 215-236. 
Hareli, S., and Weiner, B. (2002), "Social emotions and personality inferences: A scaffold for a new direction in the study of achievement motivation", Educational Psychologist, Vol.37 No.3, pp. 183-193.

Hayward, M. L. A., and Hambrick, D. C. (1997), "Explaining the premiums paid for large acquisitions: Evidence of CEO hubris", Administrative Science Quarterly, Vol.42 No.1, pp. 103-127.

Hiltz, S. R., Johnson, K., and Turoff, M. (1986), "Experiments in group decision making communication process and outcome in face-to-face versus computerized conferences", Human Communication Research, Vol.13 No.2, pp. 225-252.

Hogan, J., Hogan, R., and Kaiser, R. B. (2011), "Managerial derailment”, in Zedeck, S. (Ed.), APA handbook of industrial and organizational psychology, American Psychological Association, Washington, Vol. 3, pp. 555-575.

Huse, M. (2007), Boards, governance and value creation: The human side of corporate governance, Cambridge University Press, Cambridge.

'I was arrogant': Netflix CEO issues grovelling apology as company splits DVD mail and streaming services. (2011), viewed 20 September 2011, from www.dailymail.co.uk/news/article-2039178/Qwikster-Netflix-CEO-ReedHastings-issues-apology-company-splits-services.html

Jeung, C-W., and Yoon, H. J. (2016), "Leader humility and psychological empowerment: investigating contingencies", Journal of Managerial Psychology, Vol.31 No.7, pp.1122-1136.

Johnson, R. E., Silverman, S. B., Shyamsunder, A., Swee, H., Rodopman, O. B., Cho, E., and Bauer, J. (2010), "Acting superior but actually inferior?: Correlates and consequences of workplace arrogance", Human Performance, Vol. 23 No.5, pp. 403-427.

Kayworth, T. R., and Leidner, D. E. (2001/2002), "Leadership effectiveness in global virtual teams", Journal of Management Information Systems, Vol.18 No.3, pp. 740.

Knight, D., Pearce, C. L., Smith, K. G., Olian, J. D., Sims, H. P., Smith, K. A., and Flood, P. (1999), “Top management team diversity, group process, and strategic consensus", Strategic Management Journal, Vol.20 No.5, pp. 445-465.

Kowalski, R. M., Walker, S., Wilkinson, R., Queen, A., and Sharpe, B. (2003), "Lying, cheating, complaining, and other aversive interpersonal behaviors: A narrative examination of the darker side of relationships", Journal of Social and Personal Relationships, Vol.20 No.4, pp. 471-490.

Leslie, J. B., and Van Velsor, E. (1996), A look at derailment today: North America and Europe, Center for Creative Leadership, Greensboro, NC.

Lipman-Blumen, J. (2000), Connective leadership: Managing in a changing world. Oxford University Press, New York.

Lopez, S. J., and Snyder, C. R. (2009), Oxford handbook of positive psychology, Oxford University Press, New York.

Ma, H., and Karri, R. (2005), "Leaders beware: Some sure ways to lose your competitive advantage", Organizational Dynamics, Vol.34 No.1, pp. 63-76.

MacDonald, B. (2007), Execugame player's manual. Unpublished manuscript. 
Magner, C. (2008), "Contextual Leadership development: A South African perspective”, European Business Review, Vol.20 No.2, pp. 128-141.

Martyn, K. (2006), "Decision-making in a corporate boardroom: Inside the black box", Unpublished Doctoral Thesis, Massey University, New Zealand.

Mayle, D., and Henry, J. (2006), Managing innovation and change (4th ed.), Sage, London.

Metcalf, L., and Benn, S. (2013), "Leadership for sustainability: an evolution of leadership ability", Journal of Business Ethics, Vol.112, pp. 369-384.

Millikin, J. P., and Fu, D. (2005), "The global leadership of Carlos Ghosn at Nissan”, Thunderbird International Business Review, Vol.47 No.1, pp. 121-137.

Morris, J. A., Brotheridge, C. M., and Urbanski, J. C. (2005), "Bringing humility to leadership: Antecedents and consequences of leader humility", Human Relations, Vol.58 No.10, pp. 1323-1350.

Moyer, E. (2011). Netflix CEO: I slid into arrogance. viewed on 19 September 2011, from http://news.cnet.com/8301-1023 3-20108055-93/netflix-ceo-i-slid-intoarrogance/

Newman, J. F., Tyler, L. and Dunbar, D. M. (2001), “CEO performance appraisal: Review and recommendations", Journal of Healthcare Management, Vol.46 No.1, pp. 21.

Nielsen, R., Marrone, J., and Slay, H. (2010), "A new look at humility: Exploring the humility concept and its role in socialized charismatic leadership", Journal of Leadership \& Organizational Studies, Vol.17 No.1, pp. 33-43.

Nithiyanandan, L. (2011). Are CEOs expected to be magicians? Viewed from http://www.kellyocg.com/Knowledge/White_Papers/Are_CEOs_Expected_to_be _Magicians/

Nkomo, S. M., and Kriek, D. (2011), "Leading organizational change in the 'new' South Africa", Journal of Occupational and Organizational Psychology, Vol.84, pp.453-470.

Ou, A. Y. (2011), “CEO humility and its relationship with middle manager behaviors and performance: Examining the CEO-middle manager interface”, Unpublished Doctoral Thesis, Arizona State University, Phoenix, AZ.

Ou, A. Y., Waldman, D. A., and Peterson, S. J. (2015), "Do Humble CEOs Matter? An Examination of CEO Humility and Firm Outcomes", Journal of Management, Doi: $10.1177 / 0149206315604187$.

Owens, B. P. (2009), “Humility in organizational leadership”, Unpublished Doctoral Thesis, University of Washington, Seattle, WA.

Pallant, J. (2010), SPSS survival manual: A step by step guide to data analysis using SPSS. McGraw-Hill International, Maidenhead.

Paulhus, D. L. (1998), "Interpersonal and intrapsychic adaptiveness of trait selfenhancement: A mixed blessing?”, Journal of Personality and Social Psychology, Vol.74 No.5, pp. 1197.

Pearce II, J. A., and Zahra, S. A. (1991), "The relative power of CEOs and boards of directors: Associations with corporate performance", Strategic Management Journal, Vol.12 No.2, pp. 135-153. 
Raelin, J. A. (2016), "It's not about the leaders: It's about the practice of leadership", Organizational Dynamics, Vol.45, pp. 124-131.

Ranft, A. L., Zinko, R., Ferris, G. R., and Ronald Buckley, M. (2006), "Marketing the image of management: The costs and benefits of CEO reputation", Organizational Dynamics, Vol.35 No.3, pp. 279-290.

Resick, C. J., Whitman, D. S., Weingarden, S. M., and Hiller, N. J. (2009), “The brightside and the dark-side of CEO personality: Examining core self-evaluations, narcissism, transformational leadership, and strategic influence", Journal of Applied Psychology, Vol.94 No.6, pp. 1365-1381.

Riordan, C. M., and Shore, L. M. (1997), "Demographic diversity and employee attitudes: An empirical examination of relational demography within work units", Journal of Applied Psychology, Vol.82 No.3, pp. 342-358.

Roberts, J., McNulty, T., and Stiles, P. (2005), "Beyond agency conceptions of the work of the non-executive director: Creating accountability in the boardroom", British Journal of Management, Vol.16, pp. 5-26.

Ryan, T., and Morgan, J. P. (2007), "Modern experimental design", Journal of Statistical Theory and Practice, Vol.1 No. 3-4), pp.501-506.

Salanove, M., Llorens, S., Cifre, E., and Martínez, I. M. (2012), "We need a HERO! Toward a validation of the Healthy and Resilient Organisation (HERO) Model", Group \& Organization Management, Vol.37 No.6, pp. 785-822.

Sedikides, C., and Gregg, A. P. (2001), "Narcissists and feedback: Motivational surfeits and motivational deficits", Psychological Inquiry, Vol.15 No.4, pp. 237-239.

Seneque, M., and Bond, C. (2012), "Working with the complexities of transformational change in a society in transition: A South African perspective", European Business Review, Vol.24 No.5, pp. 425-443.

Silverman, S. B., Johnson, R. E., McConnell, N., and Carr, A. (2012), “Arrogance: A formula for leadership failure", TIP: The Industrial-Organizational Psychologist, Vol.50 No.1, pp. 21-28.

Sousa, M., and Van Dierendonck, D. (2017), "Servant Leadership and the Effect of the Interaction Between Humility, Action, and Hierarchical Power on Follower Engagement", Journal of Business Ethics, Vol.141, pp.13-25.

Steiner, I. D. (1986), "Paradigms and groups", in Berkowitz, L. (Ed.), Advances in experimental social psychology, Wiley, New York, Vol. 19, pp. 251-289.

Tosi, H. L., Misangyi, V. F., Fanelli, A., Waldman, D. A., and Yammarino, F. J. (2004), "CEO charisma, compensation, and firm performance", The Leadership Quarterly, Vol. 15 No.3, pp. 405-420.

Treadwell, T., Lavertue, N., Kumar, V. K., and Veeraraghavan, V. (2001), “The group cohesion scale-revised: Reliability and validity", International Journal of Action Methods, Vol.54 No.1, pp. 3-12.

Trumpeter, N., Watson, P. J., and O'Leary, B. J. (2006), "Factors within multidimensional perfectionism scales: Complexity of relationships with selfesteem, narcissism, self-control, and self-criticism", Personality and Individual Differences, Vol.41 No.5, pp. 849-860. 
Van Vugt, M., Jepsomn, S.F., Hart, C.M., and De Cremer, D. (2004), "Autocratic leadership in social dilemmas: A threat to group stability", Journal of Experimental Social Psychology, Vol.40 No.1, pp. 1-13.

Vera, D., and Rodriguez-Lopez, A. (2004), "Strategic virtues: Humility as a source of competitive advantage", Organizational Dynamics, Vol.33 No.4, pp. 393-408.

Wall, T. D., Michie, J., Patterson, M., Wood, S. J., Sheehan, M., Clegg, C. W., and West, M. (2004), "On the validity of subjective measures of company performance", Personnel Psychology, Vol.57 No.1, pp. 95-118.

Walters, K. N., and Diab, D. L. (2016), "Humble Leadership: Implications for psychological safety and follower engagement", Journal of Leadership Studies, Vol.10 No.2, pp. 7-18.

Wang, G., Holmes, R. M., Oh, I. S., and Zhu, W. (2015), "Do CEOS matter to firm strategic actions and firm performance? A meta-analytic investigation based on upper echelons theory”, Personnel Psychology, 2016, pp. 1-88.

Wefald, A. J. D., and Downey, R.G. (2009), "Construct dimensionality of engagement and its relation with satisfaction”, Journal of Psychology, Vol.143 No.1, pp. 91.

Westphal, J. D., Seidel, M. L., and Stewart, K. J. (2001), "Second-order imitation: Uncovering latent effects of board network ties", Administrative Science Quarterly, Vol. 46 No.4, pp. 717-747.

Yamak, S., Nielsen, S., and Escribá-Esteve, A. (2014), "The role of external environment in Upper Echelons Theory: A review of existing literature and future research directions", Group \& Organization Management, Vol.39 No.1, pp. 69109.

Yukl, G. (2001), Leadership in organisations, Prentice-Hall, Upper Saddle River, NJ.

Zaccaro, S. J. (2007), "Trait-based perspectives of leadership", American Psychologist, Vol.62 No.1, pp. 6-16. 